\title{
Bank Size and Financial Risk Exposure on Financial Performance of Commercial Banks in Kenya
}

\author{
Konya M. Nelly ${ }^{1}$, Jagongo Ambrose ${ }^{1} \&$ Kosimbei George ${ }^{2}$ \\ ${ }^{1}$ School of Business, Kenyatta University, Kenya \\ ${ }^{2}$ School of Economics, Kenyatta University, Kenya \\ Correspondence: Konya M. Nelly, Ph. D., School of Business, Kenyatta University, Kenya.
}

Received: August 3, 2019

doi:10.5430/ijfr.v10n6p250
Accepted: September 13, 2019

Online Published: September 17, 2019

URL: https://doi.org/10.5430/ijfr.v10n6p250

\begin{abstract}
The performance of banks in Kenya has become a major concern for economics and policy makers due to the role of banks remaining central in financing economic activities. The study sought to establish the effect of bank size and financial risk exposure on financial performance of commercial banks in Kenya. The descriptive research design and a positivist approach were adopted. The Berger and Hannan approach was used to establish the relationship between bank size, financial risk exposure and the moderating effect of macroeconomic variable on the financial performance of commercial banks in Kenya. Various diagnostic tests were carried out and the study data structure was panel hence Stata was employed to determine the relationship between the variables. In conclusion, banks need to grow bank sizes where they enjoy both economies of scale and scope. The Kenyan Treasury should design policies that would increase the capital size, liquidity requirements and deposit insurance premiums; this may assist in enlarging the size of banks to a level where they are fairly equal with none having relative market power to drive the market. Areas of further research may include but not limited to considering other variables besides the financial risk exposure and bank size in determining their effect on the financial performance of commercial banks in Kenya. The research may as well be done in the East African or African context. The further studies should seek to leverage on mixed research approaches that utilize both quantitative and qualitative research.
\end{abstract}

Keywords: bank size, financial risk exposure, financial performance, commercial banks, Berger and Hannan approach

\section{Introduction}

The financial performance analysis of commercial banks has been of great interest to academic research since the Great Depression Intern in the 1940's. In the last two decades, studies have shown that commercial banks in Sub-Saharan Africa (SSA) are more profitable than the rest of the world with an average Return on Assets of 2 percent (Flamini, Valentina, McDonald, \& Liliana, 2009). One of the major reasons behind high return in the region is the investment in risky ventures. The other possible reason for the high profitability in commercial banking business in SSA is the existence of a huge gap between the demand for bank service and the supply thereof. That means, in SSA the number of banks are few compared to the demand for the services; as a result, there is less competition and banks charge high interest rates. This is especially true in East Africa where the few government owned banks take the lion's share of the market. In Kenya, the banking industry has experienced major transformations over the past decades of deregulation and the globalization of financial markets. Consequently, as a rational response to the financial sector liberalization, the banking system seems to have become a more concentrated sector. The performance of banks has become a major concern for economics and policy makers because the role of banks remains central in financing economic activities (Arif, Khan \& Iqbal, 2013). Banks are the major source of debt financing for business and non-business enterprises in Kenya. Therefore, the stability of the banking industry is of paramount importance to the financial system as it plays an imperative role in the operation of an economy.

The relationship between market structure and performance has been treated within the framework of Structure-Conduct-Performance (SCP) paradigm. The original SCP interprets performance as a result of the exogenous structure of the market which influences banks' conduct. The SCP paradigm assumes that a higher bank concentration allows a higher degree of cooperation between them. According to SCP approach, the level of concentration in the banking market gives rise to potential market power by banks, which may raise their profitability. Banks in more concentrated markets are most likely to make 'abnormal profits' by their ability to lower deposit rates and charge 
higher loan rates as a result of collusive (explicit or tacit) or monopolistic reasons, than firms operating in less concentrated markets irrespective of their efficiency (Tregenna, 2009). Most studies on the problem of bank diversification and performance have been discussed in many papers. Majority of the studies highlight the positive effect of diversification on the performance and on the decrease of risks. Acharya, Saunders, and Hasan (2002) argue that diversification, based on traditional portfolio theory wisdom, leads to greater safety for financial institutions. Chatti, Kablan, and Yousfi (2010) analysed the performance and the choice of portfolio in banks and the results showed that corporate and investment activity increases significantly return on assets. However, retail and commercial activity improves the results and performance of these banks.

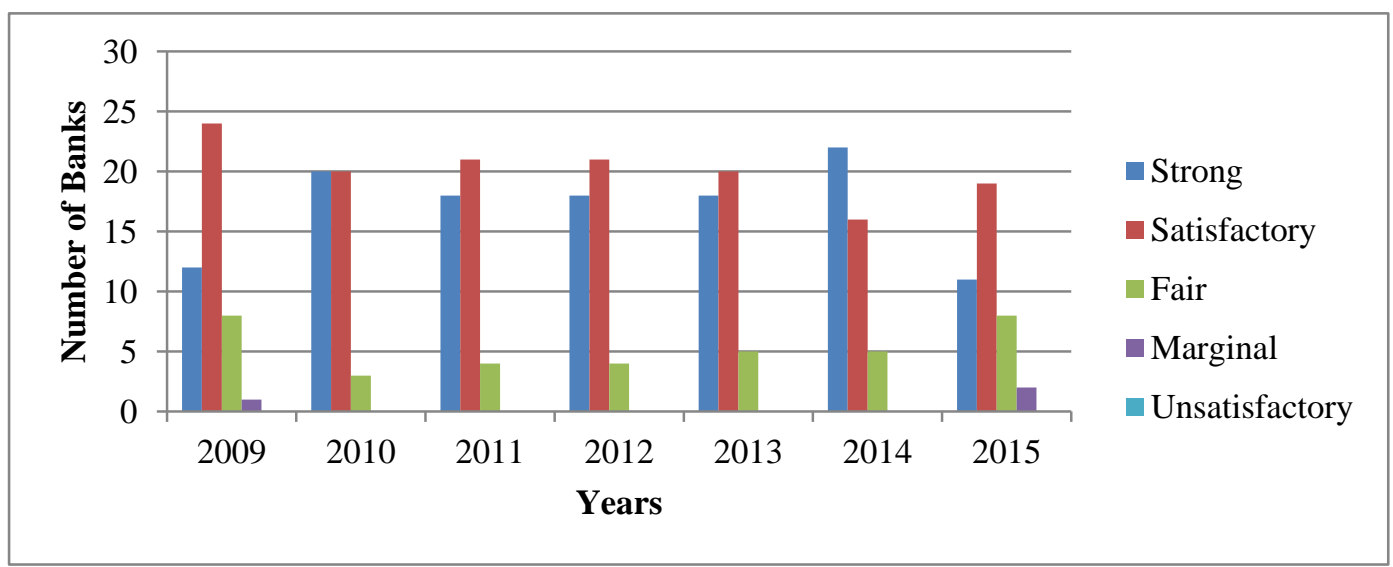

Figure 1. Bank performance ratings 2009-2015

Source: Author, (2018)

Figure 1 shows the inconsistency in the bank performance ratings between 2009 and 2015 in the Kenya. Despite the sector being stable and resilient as evidenced by the growth in the balance sheet, most banks posted satisfactory results. In 2014, more than half of the banks posted strong performance while in 2015 there was a drop to around a quarter of the banks having strong performance, and less than 20 banks had satisfactory results. This was partly due to slowdown in growth in China and the sluggish recovery in the Eurozone. The global financial markets were also volatile in most of 2015 following uncertainty in respect of the timing of the increase in U.S. interest rates, and the easing of monetary policy in the Eurozone (CBK, 2016). Overall, the impact of the adverse global developments on Kenya was minimal due to the diversification of its economy and a stable financial sector. Two banks were placed in receivership in 2015 due to their unique circumstances.

\subsection{Objectives}

The general objective of the study was to determine the effect of bank size and financial risk exposure on financial performance of Commercial Banks in Kenya.

Specifically, the study sought to achieve the following specific objectives:

i. To determine the effect of bank size on financial performance of Commercial Banks in Kenya.

ii. To establish the effect of financial risk exposure on financial performance of Commercial Banks in Kenya.

iii. To determine the moderating effect of macroeconomic variable on bank size and financial performance of Commercial Banks in Kenya.

iv. To determine the moderating effect of macroeconomic variable on financial risk exposure and financial performance of Commercial Banks in Kenya.

\section{Statement of the Problem}

Owing to the importance of the banking industry performance in influencing the macroeconomic stability, a number of country specific studies on the banking industry have been undertaken, for example, Kamau (2011); Ncube (2009); Aikaeli, (2008); Ikhide (2008); and Adongo et-al., (2005). However, these studies presented mixed results and they were not conclusive on how bank size affects performance. 
Various changes in the commercial banking industry such as bank restructuring, privatization and bank prudential regulations by $\mathrm{CBK}$ have been done to improve the performance in the commercial banking industry (Deloitte Kenya, 2012). Past studies (Fiordelisi et.al., 2010; Berger \& DeYoung, 1997; Ikhide, 2009; Turati, 2003; Hussein, 2000; Blocher, 2009; Kiweu \& Ndulu, 2012) were concerned with financial performance. Studies on financial performance, such as Heremans, (2007), Al-Tamimi \& Hassan (2010), Aburime (2005), Demirguc-Kunt and Huizinga (2000) and Goddard et al., (2004) used linear models to estimate the impact of various factors that may be important in explaining performance. Despite the empirical evidence cited demonstrating that it is possible to conduct a meaningful analysis of financial performance (Bikker \& Bos, 2005), the major conclusion is that all models focus on a single variable instead of a set of variables as theory prescribes.

Some of the previous studies show contradicting findings on the relationship between bank characteristics and financial performance of banks. For example, Isik and Hassan (2002) and Isik, Omran and Hassan (2016) showed that average financial performance decrease with increase in bank size. In contrast, Berger and Mester (2003) and Isik and Topuz (2016) noted a slight increase in financial performance with bank size which may have been induced by competitive pressures; they concluded that as banks grew larger, they were equally able to control costs but it became harder to create revenue efficiently. The study by Kraft et al., (2002) revealed that financial performance did not vary much across bank size.

From the foregoing literature, the study factored in bank size and financial risk exposure variables. Also, the study was done in Kenyan context since most studies have been done in the African context and the developing economies so as to determine the effect of bank size and financial risk exposure on financial performance of commercial banks in Kenya in attempt to fill the existing gap of knowledge body.

\subsection{Research Hypotheses}

The study was guided by the following null hypotheses:

$H_{01}$ : Bank size does not have a significant effect on financial performance of Commercial Banks in Kenya.

$H_{02}$ : Financial risk exposure does not have a significant effect on financial performance of Commercial Banks in Kenya.

$H_{03}$ : Macroeconomic variable does not have significant effect on bank size and financial performance of Commercial Banks in Kenya.

$H_{04}$ : Macroeconomic variable does not have significant effect on financial risk exposure and financial performance of Commercial Banks in Kenya.

\section{Methodology}

The research adopted a positivist approach because of the use of quantitative tools and techniques that emphasize measuring and counting (Saunders, et.al., 2009). In addition, the research used hypotheses in designing the findings, which was be taken from past studies. The study adopted descriptive research design intended to establish the effect of bank size, financial risk exposure, and the moderating effect of macroeconomic variable on financial performance of commercial banks in Kenya, which were of interest to the researcher data (Creswell, 2007). The research was conducted to provide a better understanding of the effect of bank size on financial performance of commercial banks in Kenya. The process and ultimate result was pegged on data obtained from archives of KBA and CBK's financial.

Descriptive research design was adopted since the major emphasis was to gain ideas and insights on the causal - effect relationship between bank size, financial risk exposure, and the moderating effect of macroeconomic variable on the financial performance of banks (Bordens \& Abboth, 2002). Using statistical analysis tools, the researcher carried out panel econometric analysis mainly pooled regressions since the study was dealing with panel data (McManus, 2011). Correlation matrix on all variables aided in analyzing the statistical interaction of the variables hence capable of concluding the correlation among them. Based on the model specified by the Berger and Hannan (1993), the study developed a model studying the relationship between the bank size, financial risk exposure, macroeconomic variable, and financial performance. In order to determine the relationship, the following model was estimated:

$$
\pi_{i t}=\alpha_{0}+\alpha_{1} N A_{i t}+\alpha_{2} L A_{i t}+\alpha_{3} C D_{i t}+\alpha_{4} M R_{i t}+\alpha_{5} C R_{i t}+\alpha_{6} L R_{i t}+\alpha_{7} D G_{i t}+\varepsilon_{i t}
$$

In order to test the moderation effect of macroeconomic variable (DG) on bank size and financial risk exposure on financial performance of Commercial Banks in Kenya, interaction variable between macroeconomic variable (DG) and bank size indicators (NA, LA, CD) was generated. The moderation model was estimated with the following multiple panel regression equations which were added to the model as indicated in equations (2) to equation (4); 


$$
\begin{aligned}
\pi_{i t} & =\alpha_{0}+\alpha_{1} N A_{i t}+\alpha_{2} M R_{i t}+\alpha_{3} C R_{i t}+\alpha_{4} L R_{i t}+\alpha_{5} D G_{i t}+\alpha_{6} N A_{i t} \cdot D G_{i t} \\
& +\alpha_{7} M R_{i t} \cdot D G_{i t}+\alpha_{8} C R_{i t} . D G_{i t}+\alpha_{9} L R_{i t} \cdot D G_{i t}+\varepsilon_{i t} \\
\pi_{i t} & =\alpha_{0}+\alpha_{1} L A_{i t}+\alpha_{2} M R_{i t}+\alpha_{3} C R_{i t}+\alpha_{4} L R_{i t}+\alpha_{5} D G_{i t}+\alpha_{6} L A_{i t} . D G_{i t} \\
& +\alpha_{7} M R_{i t} . D G_{i t}+\alpha_{8} C R_{i t} . D G_{i t}+\alpha_{9} L R_{i t} . D G_{i t}+\varepsilon_{i t} \\
\pi_{i t} & =\alpha_{0}+\alpha_{1} C D_{i t}+\alpha_{2} M R_{i t}+\alpha_{3} C R_{i t}+\alpha_{4} L R_{i t}+\alpha_{5} D G_{i t}+\alpha_{6} C D_{i t} . D G_{i t} \\
& +\alpha_{7} M R_{i t} . D G_{i t}+\alpha_{8} C R_{i t} . D G_{i t}+\alpha_{9} L R_{i t} . D G_{i t}+\varepsilon_{i t}
\end{aligned}
$$

Where: Equation 2 is model 1 in which bank size is measured by net assets of the bank

Equation 3 is model 2 in which bank size is measured by number of loan accounts

Equation 4 is model 3 in which bank size is measured by amounts of customer deposits

$\pi$ - Financial performance

$\alpha_{0}-$ Intercept

$\alpha_{1}-\alpha_{9}-$ Coefficient parameters

NA - Net assets (bank size)

LA - Loan accounts (bank size)

$\mathrm{CD}$ - Customer deposits (bank size)

MR - Market risk

$\mathrm{CR}$ - Credit risk

LR - Liquidity risk

DG - Kenya GDP growth rate

$\varepsilon_{i t}$ - Error term where $i$ is cross sectional and $t$ time identifier

Note that $i=1,2,3 \ldots 43$ since the researcher was analysing 43 commercial banks while $t=1,2, \ldots, 7$ since the analysis captured seven years. Therefore, the total observations were: $\mathrm{NT}=301$.

The target population in this study was all the 43 commercial banks in Kenya. A census study was conducted because the entire population was taken as sample. The choice of the population was informed by the availability of data on the key variables hence the consideration of the 43 commercial banks in the Kenyan banking industry. Sampling did not apply to the study since a census study was undertaken. Since the population was small, census was adopted for this study (McLennan, 1999). The study used secondary data. The secondary data was obtained from KBA's comprehensive archive of the 43 commercial banks and from CBK, Banking Division for the period of study 2009 to 2015. The period was informed by the global financial crisis of 2007/2009 whose effects spilled over to the country up to early 2013. The data from KBA was on profitability, while data from CBK was on bank size, financial risk exposure and the macroeconomic variables from 2009 to 2015. The 43 commercial banks comprised of 26 locally-private owned commercial banks, 14 commercial banks were foreign owned, and 3 local public owned commercial banks.

The study used secondary panel data from secondary sources, that is, data not directly compiled by the researcher obtained from the published results of the banks and central bank industry supervision reports. According to Frees (2004), panel data refers to data that is obtained by studying a group of individuals repeated for a period of time and is also commonly referred to as longitudinal data in natural sciences and pooled cross-sectional time series data in social sciences. The data extracted from the financial statements of commercial banks were from the income statements, statement of financial position and this related for bank-level information such as net assets, number of loans accounts, deposits, market risk, liquidity risk and credit risk. Information on Kenya's real GDP growth rate was obtained from various statistical bulletins for the period 2009-2015. Document reviews were used to collect the financial data for the period 2009-2015.

Diagnostics tests were used to addresses the various forms of bias that may occur in research aiming to evaluate the accuracy of diagnostic tests (Feinstein, 2002). The study carried out various diagnostic tests to investigate whether the assumptions of linear regression analysis were satisfied by running statistical and econometric tests. The statistical tests involved t-test and F-tests. The test was necessary in determining the statistical significance of individual 
parameters and joint significance with the aid of the relevant distribution tables. The econometric tests included; autocorrelation, multicollinearity, heteroscedasticity, unit root test, and the normality test (Gujarati, 2003). Also, the analysis endowed regression analysis with both a spatial and temporal dimension. Therefore, to ensure the validity and reliability of the estimated model parameters, the study applied the Hausman test in choosing on whether to run the fixed effects or the random effects model.

\subsection{Conceptual Framework}

This study focused on assessing functional relationship between the bank size, financial risk exposure and resultant financial performance and it was guided by the Market Power and the Efficiency Structure Theories which has been treated within the framework of Structure-Conduct-Performance paradigm. The independent variables were bank size the financial risk exposure. The dependent variable was the financial performance while the moderating variable was the macroeconomic variable.

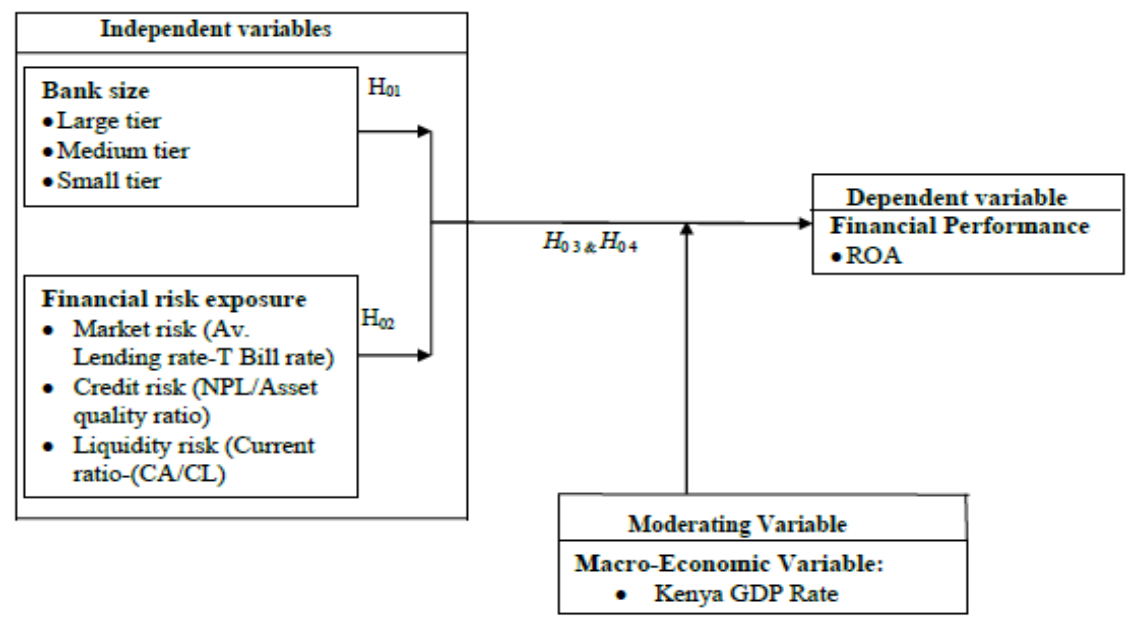

Figure 2. Conceptual framework

Source: Author (2018)

\section{Empirical Results, Interpretation and Discussions}

The study presents research findings of the study on the effect of bank size and financial risk exposure on financial performance of commercial banks in Kenya. The data was collected from secondary sources and it was extracted from the annual bank supervision reports published by Central Bank of Kenya and the Kenya Bankers Association' archives.

\subsection{Data Analysis and Interpretation}

The following is the data analysis and interpretation:

Table 1. Descriptive statistics

\begin{tabular}{llllllll}
\hline Variables & Min & Max & Mean & Variance & Std. Dev. & Skewness & Kurtosis \\
\hline ROA & -261.290 & 23.199 & 2.464 & 386.780 & 19.667 & -14.974 & 187.586 \\
\hline Bank size (assets) & 0.040 & 14.000 & 3.859 & 9.953 & 3.155 & 2.008 & 1.026 \\
\hline Bank size (loan acc) & 0.010 & 37.400 & 2.630 & 34.741 & 5.894 & 4.407 & 21.843 \\
\hline Bank size (deposits) & 0.010 & 14.100 & 2.905 & 9.682 & 3.112 & 2.830 & 6.853 \\
\hline Credit risk & 0.010 & 76.760 & 9.351 & 113.820 & 10.669 & 3.075 & 13.972 \\
\hline Liquidity risk & 3.310 & 107.700 & 44.629 & 357.945 & 18.919 & 1.808 & 4.937 \\
\hline Market risk & 1.740 & 11.580 & 8.532 & 11.831 & 3.440 & -1.866 & 2.672 \\
\hline Kenya GDP Growth Rate & 3.300 & 8.400 & 5.810 & 3.906 & 1.976 & 0.690 & 2.480 \\
\hline S
\end{tabular}

Source: Research Data (2018) 
Based on Table 1, the results show ROA has a minimum of -261.29 and a maximum of 23.199 of the extent to which the variable deviates from its main value. 19.667 is the extent to which ROA deviates from the mean value of 2.464. Compared to other countries financial performances as expressed by the mean score of 2.464 for ROA, the results imply that Kenya's financial performance is average. This is consistent with the findings of Flamini et al., (2009) who states that the average ROA in Sub-Saharan Africa (SSA) is about 2\% thus the average ROA of Kenyan banks is about average of the SSA. Also, the market share of banks (bank size) is positive and this implies that market share plays a significant role in impacting on the financial performance of Kenyan commercial banks. This finding is in support of both the Structure Conduct Performance (SCP) and Relative Market Power (RMP) hypothesis. Banks in high concentration markets are able to earn higher profits while banks with relative high market power in terms of net asset share earn higher profits through the high interest margins (Kamau \& Were, 2013). The bank size (net assets), bank size (loan accounts) and bank size (customer deposits) had a mean of 3.859, 2.630 and 2.905 respectively. This implies that the Kenyan banking industry market is highly concentrated and this has highly influenced financial performance. The study supports the RMP and SCP hypothesis that market power enjoyed by individual banks and collusive power enjoyed by large banks have a significant influence on financial performance in Kenya.

The bank size (loan accounts) has a maximum of 37.4 of the extent to which it deviates from its main value of 5.894. 5.894 is the extent to which bank size (loan accounts) deviates from the mean value of 2.630. This shows that banks have a high loan book that may lead to high non-performing loans thereby negatively impacting on their financial performance. This also indicates that most banks' source of income is interest earned on bank loans. It also implies that most of the banks' products and services are tailor made to suite their clientele who are interested in loans. It also indicates that most people open bank accounts with the intention of applying for loan facilities from the banking industry.

Under the bank size variable, the net assets have the highest minimum of 0.040 and the lowest maximum of 14.0 as compared to the loan account and customer deposits. This could imply that most banks are highly liquid and have few assets owned by them. This is risky because when a bank is bankrupt, they lack assets as a backup to their financial crisis. On the other hand, this may imply that banks are able to settle obligations with immediacy (Drehmann \& Nikolaou, 2013). Efficient liquidity management requires maintaining sufficient cash reserves on hand while also investing as many funds as possible to maximise earnings. The results also imply that banks do not need to be worried about the maturity transformation if they have assets that can be sold without bearing any loss. Whereas, banks having assets that are going to be matured in a shorter period may have a less need to keep the liquid assets (Ahmed et.al., 2015).

The bank size (loans) mean is 2.630 and the bank size (customer deposits) is 2.905 . This could imply that banks use customer deposits to lend; customer deposits are one of the cheapest sources of fund due to the high margin between deposit and lending rate that banks utilise to generate income (Ongore \& Kusa, 2013). This also implies that Kenyan banks target domestic resources mainly customer deposits for their banking business. It also implies that banks keep more than the statutory liquidity requirement. It also implies that besides bank customers investing in fixed deposits, they at the same time apply for loan facilities from the same banks.

Liquidity risk has the highest standard deviation measure of dispersion from its main value of 18.919 as compared to the credit risk and market risk. Also, liquidity risk has the highest maximum of 107.700 of the extent to which it deviates from its main value of 18.919. In addition, 18.919 is the extent to which liquidity risk deviates from the mean value of 44.629. Liquidity risk has a variance of 357.945 indicating the deviation from its value of 18.919. This implies that banks are unable to easily liquidate or offset a particular position at or near the last traded market price due to inadequate market depth or market disruptions prompting them to engage in interbank lending to meet their daily transactions (Mohan, 2003). The liquidity risk may arise due to liquidity mismatch which is measured in terms of liquidity gap (Plochan, 2007).

There is a possibility of the risk arising due to recessionary economic conditions, causing less resource generation thereby increasing the demand of depositors. This may cause the failure of a given bank or even the entire banking system due to contagion effect (Brunnermeier \& Yogo, 2009). The results may also imply that there is a breakdown or delay in cash flows from borrowers or early termination of the projects (Diamond \& Rajan, 2005). Also, disruptions in financial markets as well as entry and exit of major market makers or large institutional investors can affect liquidity because funding is no longer readily available and if it is available, it is expensive (BCBS, 2009). Available liquidity at any point is also a function of the size of trades a bank transacts at relative to the market (Marrison, 2005). As banks strive to transform their short-term deposits into long-term assets, they are always going to be at risk. The banks should therefore have a good understanding of the market in order to be able to measure and manage the risk exposure to them. 
They should also create mismatches between asset and liability maturity; to ensure that the mismatches keep enough funds flowing; the banks should both increase assets and meet obligations when customers ask for their money.

The credit risk has a minimum of 0.010 and a maximum of 76.76 of the extent to which it deviates from its main value. 10.669 is the extent to which credit risk deviates from the mean value of 9.351. This indicates the potential of a bank borrower failing to meet their obligations in accordance to agreed terms. Credit risk is most likely caused by loans, acceptances, interbank transactions, trade financing, foreign exchange transactions, financial futures, swaps, bonds, credit cards, equities, options and in the extension of commitments and guarantees, and settlement transactions. Factors like unsteady income by bank customers, low credit score, employment type, collateral assets, and others determine the credit risk associated with the borrower (Sharma, 2003). Credit risk is also as a result of macro forces affecting the economy or specific markets or even specific individuals.

Market risk has the lowest standard deviation measure of dispersion from its main value of 3.440 as compared to the credit risk and liquidity risk. The market risk has a minimum of 1.74 and a maximum of 11.58 of the extent to which it deviates from its main value. 3.440 is the extent to which market risk deviates from the mean value of 8.532 . This implies that few banks are at risk of losses due to changes in equity prices, credit spreads, foreign exchange rates, commodity prices, interest rates and other indicators whose values are set in the market. This is because the market risk is prevalent amongst banks that are into investment banking since they are active in the capital markets (Kumar et al., 2005). In Kenya, thirty-nine commercial banks have investment in the capital market.

In table 4.1.1, ROA and market risk are negatively skewed with values of $-14.974,-2.979$, and -1.866 respectively. The bank size (assets, loan accounts, and deposits), credit risk, liquidity risk, and Kenya GDP growth rate growth rate are positively skewed. The results show a non-normal distribution for all the variables. This implies that the variables are non-normally distributed. A distribution is leptokurtic when the kurtosis value is a large positive. The ROA, bank size (loan accounts), and credit risk are suffering from leptokurtic. ROA, bank size (loan accounts), credit risk, bank size (assets), bank size (deposits), and liquidity risk have fat tails because their kurtosis is greater than 3.0. A distribution is platykurtic when the kurtosis is negative. Market risk, and Kenya GDP growth rate have narrow tails because their kurtosis is less than 3.0; this implies that they have negative kurtosis hence narrow tails.

Table 2. Correlational matrix

\begin{tabular}{|c|c|c|c|c|c|c|c|c|}
\hline Variables & ROA & $\begin{array}{l}\text { market } \\
\text { share } \\
\text { (assets) }\end{array}$ & $\begin{array}{l}\text { market } \\
\text { share } \\
(\text { acc })\end{array}$ & $\begin{array}{l}\text { market } \\
\text { share } \\
\text { (deposits) }\end{array}$ & $\begin{array}{l}\text { Credit } \\
\text { risk }\end{array}$ & $\begin{array}{l}\text { Liquidity } \\
\text { risk }\end{array}$ & $\begin{array}{c}\text { Market } \\
\text { Risk }\end{array}$ & KGR \\
\hline $\mathrm{ROA}$ & 1.000 & & & & & & & \\
\hline market share (assets) & 0.123 & 1.000 & & & & & & \\
\hline market share (acc) & 0.075 & 0.688 & 1.000 & & & & & \\
\hline market share (deposits) & 0.121 & 0.993 & 0.668 & 1.000 & & & & \\
\hline Credit risk & -0.084 & -0.123 & -0.045 & -0.112 & 1.000 & & & \\
\hline Liquidity risk & -0.031 & -0.220 & -0.147 & -0.222 & -0.105 & 1.000 & & \\
\hline Market risk & -0.002 & -0.001 & -0.001 & 0.002 & 0.052 & 0.032 & 1.000 & \\
\hline KGR & 0.045 & 0.002 & 0.003 & 0.002 & -0.286 & -0.064 & 0.174 & 1.000 \\
\hline
\end{tabular}

Source: Research Data (2018)

Based on Table 2, the results are supposed to give spearman correlation coefficient which is to range from -1 to +1 , where 1 is total positive correlation, 0 is no correlation, and -1 is total negative correlation. If the results are less than 0.5 , it implies weak correlation. If the results are greater than 0.8 , it implies a strong correlation. For variables to be correlated, one variable has to be dropped to avoid multicollinearity problem. The results indicate market share (deposits) is highly correlated with a value of 0.993 , hence the variable has to be dropped from the model.

\subsection{Hypothesis Testing}

The rule for p-value method of hypotheses testing is the p-value being less than 0.05 or $5 \%$ indicating that one can reject the null hypothesis at 5 percent significance level or fail to reject the null hypothesis at 5 percent significance level. 
Table 3. Hypothesis testing with bank size (net assets)

\begin{tabular}{llllll}
\hline Variables & The null hypothesis & $\begin{array}{l}\text { Computed } \\
\text { p-value }\end{array}$ & $\begin{array}{l}\text { Theoretical } \\
\text { p-value }\end{array}$ & $\begin{array}{l}\text { Comparing } \\
\text { p-value }\end{array}$ & Remark \\
\hline $\begin{array}{l}\text { Bank size } \\
\text { (net assets) }\end{array}$ & $\begin{array}{l}\mathbf{H}_{\mathbf{0 1}} \text { bank size (net assets) } \\
\text { does not affect ROA }\end{array}$ & 0.036 & $\alpha=0.05$ & $\mathrm{P}<0.05$ & Reject $\mathbf{H}_{\mathbf{0 1}}$ \\
\hline Credit risk & $\begin{array}{l}\mathbf{H}_{\mathbf{0 2}} \text { Credit risk does not } \\
\text { affect ROA }\end{array}$ & 0.001 & $\alpha=0.05$ & $\mathrm{P}>0.05$ & Reject $\mathbf{H}_{\mathbf{0 2}}$ \\
\hline $\begin{array}{l}\text { Liquidity } \\
\text { risk }\end{array}$ & $\begin{array}{l}\mathbf{H}_{\mathbf{0 2}} \text { Liquidity risk does not } \\
\text { affect ROA }\end{array}$ & 0.009 & $\alpha=0.05$ & $\mathrm{P}<0.05$ & Reject $\mathbf{H}_{\mathbf{0 2}}$ \\
\hline Market risk & $\begin{array}{l}\mathbf{H}_{\mathbf{0 2}} \text { Market risk does not } \\
\text { affect ROA }\end{array}$ & 0.018 & $\alpha=0.05$ & $\mathrm{P}>0.05$ & Reject $\mathbf{H}_{\mathbf{0 2}}$ \\
\hline $\begin{array}{l}\text { Kenya GDP } \\
\text { growth rate }\end{array}$ & $\begin{array}{l}\mathbf{H}_{\mathbf{0 3}} \text { Kenya GDP growth } \\
\text { rate does not affect ROA }\end{array}$ & 0.855 & $\alpha=0.05$ & $\mathrm{P}>0.05$ & Fail to reject $\mathbf{H}_{\mathbf{0 3}}$ \\
\hline
\end{tabular}

Source: Research Data (2018)

Under hypothesis 1 , the bank size (net assets) has a p-value of 0.036 which is less than 5\%. This implies that the null hypothesis is rejected because the bank size (net assets) has significant effect on the financial performance of commercial banks in Kenya. This is inconsistent with the findings of Kamau \& Were (2013). Also, the credit risk and market risk have p-values of 0.001 and 0.018 respectively which are less than $5 \%$. This implies that the null hypothesis is rejected accepted meaning they have a significant effect on the financial performance of commercial banks in Kenya. The liquidity risk has a p-value of 0.009 which is less than $5 \%$; implying that the null hypothesis is rejected because liquidity risk has significant effect on the financial performance of commercial banks in Kenya. Under hypothesis on the Kenya growth rate in model 1 , has a p-value of 0.855 which is greater than $5 \%$ hence the null hypothesis is accepted. This implies that the Kenya growth rate does not significantly moderate the relationship between bank size and financial risk exposure on the financial performance of commercial banks in Kenya. This relationship supports that Kenya GDP growth rate is neutral towards financial performance (Flamini et al., 2009).

Table 4. Hypothesis testing with bank size (number of loan accounts)

\begin{tabular}{llllll}
\hline Variables & The null hypothesis & $\begin{array}{l}\text { Computed } \\
\mathbf{p} \text {-value }\end{array}$ & $\begin{array}{l}\text { Theoretical } \\
\mathbf{p} \text {-value }\end{array}$ & $\begin{array}{l}\text { Comparing } \\
\mathbf{p} \text {-value }\end{array}$ & Remark \\
\hline $\begin{array}{l}\text { Bank size (no. of } \\
\text { loan accounts) }\end{array}$ & $\begin{array}{l}\mathbf{H}_{\mathbf{0 1}} \text { Bank size (no. of loan } \\
\text { accounts) does not affect } \\
\text { ROA }\end{array}$ & 0.230 & $\alpha=0.05$ & $\mathrm{P}<0.05$ & $\begin{array}{l}\text { Fail } \\
\text { reject } \mathbf{H}_{\mathbf{0 1}}\end{array}$ \\
\hline Credit risk & $\begin{array}{l}\mathbf{H}_{\mathbf{0 2}} \text { Credit risk does not } \\
\text { affect ROA }\end{array}$ & 0.010 & $\alpha=0.05$ & $\mathrm{P}<0.05$ & Reject $\mathbf{H}_{\mathbf{0 2}}$ \\
\hline Liquidity risk & $\begin{array}{l}\mathbf{H}_{\mathbf{0 2}} \text { Liquidity risk does not } \\
\text { affect ROA }\end{array}$ & 0.166 & $\alpha=0.05$ & $\mathrm{P}<0.05$ & $\begin{array}{l}\text { Fail to } \\
\text { reject } \mathbf{H}_{\mathbf{0 2}}\end{array}$ \\
\hline Market risk & $\begin{array}{l}\mathbf{H}_{\mathbf{0 2}} \text { Market risk does not } \\
\text { affect ROA }\end{array}$ & 0.072 & $\alpha=0.05$ & $\mathrm{P}<0.05$ & $\begin{array}{l}\text { Fail to } \\
\text { reject } \mathbf{H}_{\mathbf{0 2}}\end{array}$ \\
\hline $\begin{array}{l}\text { Kenya GDP growth } \\
\text { rate }\end{array}$ & $\begin{array}{l}\mathbf{H}_{\mathbf{0 3}} \text { Kenya GDP growth } \\
\text { rate does not affect ROA }\end{array}$ & 0.327 & $\alpha=0.05$ & $\mathrm{P}<0.05$ & $\begin{array}{l}\text { Fail to } \\
\text { reject } \mathbf{H}_{\mathbf{0 3}}\end{array}$ \\
\hline Soure: Resa
\end{tabular}

Source: Research Data (2018)

Under hypothesis on bank size the p-value is 0.230 which is more than $5 \%$. This implies that the null hypothesis is not rejected because the bank size has no significant effect on the financial performance of commercial banks in Kenya. The credit risk has p-value of 0.010 which are less than $5 \%$ implying that the null hypothesis and hence credit risk has a significant effect on the financial performance of commercial banks in Kenya while liquidity risk has a p-value of 0.166 respectively which is more than $5 \%$ and hence does not have a significant effect on the financial performance of 
commercial banks in Kenya. The market risk has a p-value of 0.072 which is more than $5 \%$; implying that the null hypothesis is accepted because market risk has no significant effect on the financial performance of commercial banks in Kenya. This is inconsistent with the findings of Rao \& Lakew (2012), Ramadan et al., (2011) and Ongore \& Kusa (2013). The Kenya GDP growth rate has a p-value of 0.327 which is greater than $5 \%$ hence the null hypothesis is accepted. This implies that the Kenya GDP growth rate does not significantly moderate the relationship between bank size and financial risk exposure on the financial performance of commercial banks in Kenya. This relationship supports that Kenya GDP growth rate is neutral towards financial performance (Flamini et al., 2009).

Table 5. Hypothesis testing with bank size (amount of customer deposits)

\begin{tabular}{llllll}
\hline Variables & The null hypothesis & $\begin{array}{l}\text { Computed } \\
\text { p-value }\end{array}$ & $\begin{array}{l}\text { Theoretical } \\
\text { p-value }\end{array}$ & $\begin{array}{l}\text { Comparing } \\
\text { p-value }\end{array}$ & Remark \\
\hline $\begin{array}{l}\text { Bank size (amount of } \\
\text { customer deposits) }\end{array}$ & $\begin{array}{l}\mathbf{H}_{\mathbf{0 1}} \text { Bank size (amount of } \\
\text { customer deposits does } \\
\text { not affect ROA }\end{array}$ & 0.030 & $\alpha=0.05$ & $\mathrm{P}<0.05$ & Reject $\mathbf{H}_{\mathbf{0 1}}$ \\
\hline Credit risk & $\begin{array}{l}\mathbf{H}_{\mathbf{0 2}} \text { Credit risk does not } \\
\text { affect ROA }\end{array}$ & 0.001 & $\alpha=0.05$ & $\mathrm{P}>0.05$ & Reject $\mathbf{H}_{\mathbf{0 2}}$ \\
\hline Liquidity risk & $\begin{array}{l}\mathbf{H}_{\mathbf{0 2}} \text { Liquidity risk does not } \\
\text { affect ROA }\end{array}$ & 0.003 & $\alpha=0.05$ & $\mathrm{P}<0.05$ & Reject $\mathbf{H}_{\mathbf{0 2}}$ \\
\hline Market risk & $\begin{array}{l}\mathbf{H}_{\mathbf{0 2}} \text { Market risk does not } \\
\text { affect ROA }\end{array}$ & 0.010 & $\alpha=0.05$ & $\mathrm{P}<0.05$ & Reject $\mathbf{H}_{\mathbf{0 2}}$ \\
\hline $\begin{array}{l}\text { Kenya GDP growth } \\
\text { rate }\end{array}$ & $\begin{array}{l}\mathbf{H}_{\mathbf{0 3}} \text { Kenya GDP growth } \\
\text { rate does not affect ROA }\end{array}$ & 0.680 & $\alpha=0.05$ & $\mathrm{P}<0.05$ & Fail to reject $\mathbf{H}_{\mathbf{0 3}}$ \\
\hline
\end{tabular}

Source: Research Data (2018)

Under hypothesis on the bank measured by the amount of customer deposits has a p-value of 0.030 which is less than $5 \%$. This implies that the null hypothesis is rejected because the bank size measured by the amount of customer deposits has significant effect on the financial performance of commercial banks in Kenya. This is inconsistent with the findings of Kamau \& Were (2013). Under the hypothesis, credit risk and market risk have p-values of 0.001 and 0.010 respectively which are less than $5 \%$. This implies that the null hypothesis is rejected meaning they do have significant effect on the financial performance of commercial banks in Kenya.

The liquidity risk has a p-value of 0.003 which is less than $5 \%$; implying that the null hypothesis is rejected because liquidity risk has significant effect on the financial performance of commercial banks in Kenya. This is inconsistent with the findings of Rao \& Lakew (2012), Ramadan et al., (2011) and Ongore \& Kusa (2013). Under hypothesis on the Kenya GDP growth rate, the p-value is 0.680 and is greater than $5 \%$ hence the null hypothesis is accepted. This implies that the Kenya GDP growth rate does not significantly moderate the relationship between bank size and financial risk exposure on the financial performance of commercial banks in Kenya. This relationship supports that Kenya GDP growth rate is neutral towards financial performance (Flamini et al., 2009).

\subsubsection{Summary of Hypothesis Testing}

Below is a summary of the hypothesis testing:

Table 6. Hypotheses testing summary for ROA

\begin{tabular}{llll}
\hline Model 1 & $\mathbf{H}_{\mathbf{0}}$ & Decision at 5 percent level \\
\hline Objectives & $\begin{array}{l}\text { Bank size does not have a } \\
\text { To determine effect of bank size } \\
\text { on financial performance of } \\
\text { commercial banks in Kenya }\end{array}$ & $\begin{array}{l}\text { significant effect on financial } \\
\text { performance of commercial } \\
\text { banks in Kenya }\end{array}$ & Reject $\mathrm{H}_{0}$ \\
\hline
\end{tabular}




\begin{tabular}{|c|c|c|}
\hline $\begin{array}{l}\text { To establish the effect of financial } \\
\text { risk exposure on financial } \\
\text { performance of commercial banks } \\
\text { in Kenya }\end{array}$ & $\begin{array}{l}\text { Financial risk exposure does not } \\
\text { have a significant effect on } \\
\text { financial performance of } \\
\text { commercial banks in Kenya }\end{array}$ & $\begin{array}{l}\text { Reject } \mathrm{H}_{0} \text { for Credit risk. } \\
\text { Reject } \mathrm{H}_{0} \text { for Liquidity risk } \\
\text { Reject } \mathrm{H}_{0} \text { for market risk }\end{array}$ \\
\hline $\begin{array}{l}\text { To determine the moderating } \\
\text { effect of macroeconomic variable } \\
\text { on the relationship among bank } \\
\text { size, financial risk exposure and } \\
\text { performance of commercial banks } \\
\text { in Kenya }\end{array}$ & $\begin{array}{l}\text { Macroeconomic variable does } \\
\text { not have a significant effect on } \\
\text { the relationship bank size, } \\
\text { financial risk exposure and } \\
\text { performance of commercial } \\
\text { banks in Kenya }\end{array}$ & Fail to reject $\mathrm{H}_{0}$ \\
\hline \multicolumn{3}{|c|}{ Model 2} \\
\hline Objectives & $\mathbf{H}_{0}$ & Decision at 5 percent level \\
\hline $\begin{array}{l}\text { To determine effect of bank size } \\
\text { on financial performance of } \\
\text { commercial banks in Kenya }\end{array}$ & $\begin{array}{l}\text { Bank size does not have a } \\
\text { significant effect on financial } \\
\text { performance of commercial } \\
\text { banks in Kenya }\end{array}$ & Reject $\mathrm{H}_{0}$ \\
\hline $\begin{array}{l}\text { To establish the effect of financial } \\
\text { risk exposure on financial } \\
\text { performance of commercial banks } \\
\text { in Kenya }\end{array}$ & $\begin{array}{l}\text { Financial risk exposure does not } \\
\text { have a significant effect on } \\
\text { financial performance of } \\
\text { commercial banks in Kenya }\end{array}$ & $\begin{array}{l}\text { Reject } \mathrm{H}_{0} \text { for Credit risk } \\
\text { Fail to reject } \mathrm{H}_{0} \text { for Liquidity risk } \\
\text { Fail to reject } \mathrm{H}_{0} \text { for market risk }\end{array}$ \\
\hline
\end{tabular}

\begin{tabular}{|c|c|c|}
\hline $\begin{array}{l}\text { To determine the moderating } \\
\text { effect of macroeconomic variable } \\
\text { on the relationship among bank } \\
\text { size, financial risk exposure and } \\
\text { performance of commercial banks } \\
\text { in Kenya }\end{array}$ & $\begin{array}{l}\text { Macroeconomic variable does } \\
\text { not have a significant effect on } \\
\text { the relationship bank size, } \\
\text { financial risk exposure and } \\
\text { performance of commercial } \\
\text { banks in Kenya. }\end{array}$ & Reject $\mathrm{H}_{0}$ \\
\hline \multicolumn{3}{|l|}{ Model 3} \\
\hline Objectives & $\mathbf{H}_{0}$ & Decision at 5 percent level \\
\hline $\begin{array}{l}\text { To determine effect of bank size } \\
\text { on financial performance of } \\
\text { commercial banks in Kenya }\end{array}$ & $\begin{array}{l}\text { Bank size does not have a } \\
\text { significant effect on financial } \\
\text { performance of commercial } \\
\text { banks in Kenya }\end{array}$ & Reject $\mathrm{H}_{0}$ \\
\hline $\begin{array}{l}\text { To establish the effect of financial } \\
\text { risk exposure on financial } \\
\text { performance of commercial banks } \\
\text { in Kenya }\end{array}$ & $\begin{array}{l}\text { Financial risk exposure does not } \\
\text { have a significant effect on } \\
\text { financial performance of } \\
\text { commercial banks in Kenya }\end{array}$ & $\begin{array}{l}\text { Reject } \mathrm{H}_{0} \text { for Credit risk } \\
\text { Reject } \mathrm{H}_{0} \text { for Liquidity risk } \\
\text { Reject } \mathrm{H}_{0} \text { for market risk }\end{array}$ \\
\hline $\begin{array}{l}\text { To determine the moderating } \\
\text { effect of macroeconomic variable } \\
\text { on the relationship among bank } \\
\text { size, financial risk exposure and } \\
\text { performance of commercial banks } \\
\text { in Kenya }\end{array}$ & $\begin{array}{l}\text { Macroeconomic variable does } \\
\text { not have a significant effect on } \\
\text { the relationship bank size, } \\
\text { financial risk exposure and } \\
\text { performance of commercial } \\
\text { banks in Kenya }\end{array}$ & Fail to reject $\mathrm{H}_{0}$ \\
\hline
\end{tabular}

Source: Research Data (2018)

\subsection{Summary of the Study Findings}

The study strived to establish the effect of bank size and financial risk exposure on financial performance of commercial banks in Kenya. In order to achieve this, the following research hypotheses guided the study: Bank size does not have a significant effect on financial performance of commercial banks in Kenya; Financial risk exposure does not have significant effect on financial performance of commercial Banks in Kenya; and Macroeconomic variable does not significantly moderate the relationship between bank size, financial risk exposure and financial performance of commercial banks in Kenya.

Objective one sought to determine the effect of bank size on financial performance of Commercial Banks in Kenya by 
analyzing the structural performance relationship existing in the banking industry using the Structure-Conduct-Performance literature. Bank size was measured by the market share based on net assets, loan accounts and deposits. The results indicate that bank size (i.e. assets, loan accounts, and deposits) is positive; this implies that bank size plays a major role in impacting on the financial performance of commercial banks in Kenya. The results also imply that the main source of financial performance in the Kenyan banking industry is as a result of structure or collusive power and not efficiency (Beck \& Fuchs, 2004). The findings support the Structure-Conduct-Performance and the Relative Market Power hypothesis enjoyed by the small tier, medium tier and large tier banks as evidenced in Kenya where the bank sizes (net assets) significantly affect the financial performance of commercial banks in Kenya (Kamau \& Were, 2013).

On the other hand, following the introduction of the interest rate cap in August 2016, the interest margins are lower and this has resulted in slower credit growth. Consequently, the industry' valuations have gone down significantly with industry' performance declining from 1.9x as at end of 2014 to $0.8 \mathrm{x}$ as at end of January 2017. According to CBK report, as at end of March 2016, the total net assets grew by 5.9\% from Ksh.3.4trillion in March 2015 to Ksh.3.6 trillion in March 2016, and this was mainly attributed to increased loans and advances of Ksh.170.6 billion and investment in government securities of Ksh.48.2billion. The increased investment in government securities was as a result of large banks investing surplus liquidity in risk free instruments (CBK, 2016). In addition, the capital levels increased by $5.1 \%$ from Ksh.530.1 billion in March 2015 to Ksh.557.1 billion in March 2016. The core capital increased by 6.3\% from Ksh.447 billion to Ksh.475 billion. Despite the increased capital levels, the capital ratios decreased marginally by $0.2 \%$ while the total capital to total risk weighted assets marginally decreased by $0.4 \%$.

In addition, the findings indicate that net assets affect ROA by 0.001 . The p-value of 0.001 is less than $5 \%$ implying that the net assets have significant effect on the financial performance of commercial banks in Kenya. Also, the results indicate that average ROA in Kenya is low and this means that it is important to grow bank sizes where they enjoy both economies of scale and scope. This evidence supports and is in line with the Structure-Conduct-Performance theory which states that structure and efficiency play a role in determining performance. Currently, only twenty-one commercial banks have met the Ksh.5billion core capital requirement by CBK as stipulated in the Banking Act. To meet this requirement, the banking industry has experienced mergers and acquisitions and the latest one saw Diamond Trust Bank Kenya Ltd acquiring Habib Bank Ltd in August 2017. The National Treasury has been pushing for increased capitalization of banks by proposing twice the minimum core capital to be increased from the current Ksh.1 billion to Ksh.5 billion. This has necessitated consolidation through mergers and acquisitions. In 2016, Mwalimu National Sacco acquired the stake in Equatorial Commercial Bank Ltd and rebranded to Spire Bank Ltd. Also, in 2016, K-Rep Bank Ltd rebranded to Sidian Bank Ltd in a restructuring process that costed the bank Ksh.500 million (CBK, 2016). Consequently, Bank M Tanzania acquired 51\% stake in Oriental Commercial Bank Ltd that saw the bank rebrand to M Oriental Bank Ltd. The Chase Bank in Receivership is expected to be acquired and there a proposal of consolidating all state-owned banks (National bank of Kenya Ltd, Consolidated Commercial Bank Ltd and Development Bank of Kenya Ltd) in the near future. In July 2017, Diamond Trust Bank Kenya Ltd acquired Habib Bank Ltd. The expectation from consolidation in the banking industry is for banks to be more competitive and offer favourable products to their clients.

Under bank size (loan accounts), the results indicate a high loan book that may lead to increased non-performing loans thereby negatively impacting on the financial performance of commercial banks in Kenya. As at March 2016, the banking sector's gross loans and advances increased from Ksh.2.0 trillion in March 2015 to Ksh.2.2 trillion in March 2016 translating to an increase of $20 \%$. The increment in the loan book was contributed by increased demand for credit from all the economic sectors (CBK, 2016). Policy directions by Treasury such as increasing capital size, liquidity requirements, and deposit insurance premiums may aid in enlarging the size of all banks to a level where they are fairly equal with none having relative market power to drive process in the market, thereby ensuring an ideal environment for competitive pricing and operational efficiency.

Objective two was to establish the effect of financial risk exposure on financial performance of Commercial Banks in Kenya. Financial risk exposure has been considered to have impact on the financial performance of commercial banks in Kenya. The financial risk exposure was measured by the market risk, credit risk and liquidity risk. There are mixed regression results in Model 1, Model 2 and Model 3. Kasman et al., (2011) in their study found the negative and significant effect of credit risk and market risk on bank performance. Under ROA in Model 1, 2 and 3, the regression analysis results indicate that market risk has minimal effect on financial performance of commercial banks in Kenya. This means that the overall market movement in the financial market has minimal impact on the financial performance in the banking industry. This is somehow true because during the global financial crisis in 2007/2009, there was minimal impact on the financial performance of commercial banks in Kenya because banks had positive results/growth 
(CBK, 2013).

The findings also indicate that liquidity risk affects ROA as the p-value is less than $5 \%$ except in the case where bank size is measured by the number of loan accounts implying that liquidity risk has significant effect on the financial performance of commercial banks in Kenya. This further implies that financial risk exposure can have minimal or major effect on the financial performance of banks in Kenya depending on the risk policies that are in place. The market risk is the most preferred by banks to liquidity risk and credit risk because it has the lowest standard deviation measure of dispersion. This implies that few banks in Kenya are at a risk of losses due to the changes in equity, credit, etc. However, more emphasis should be on the liquidity risk because it significantly impacts on the performance of banks irrespective of the bank size (Tier 1, 2 or 3). Treasury and CBK should review the risk policies often to guide in mitigation of risk in the industry; the same applies to all commercial banks irrespective of the tier. According to CBK, (2016), as at end of Q1 of 2016, the banking sector's average liquid assets were at 39.9\% which was the same as it was in Q1 of 2015.

However, in Models 1, 2 and 3, the regression results for credit risk and liquidity risk are varied. The results indicate that both credit risk and liquidity risk can have minimal effect as well as significant effect on the financial performance of banks. This means that financial performance is not about the banks keeping high liquid assets, issuing loans, engaging in foreign exchange transactions or trade financing; it is about net assets quality and others. It also doesn't mean that liquidity and credit status have no effect at all; it implies that the banks' financial performance is less affected by the liquidity and credit risks. Kenyan banks are known to grow their loan accounts at tremendous rates. Between 2011 and 2015, the banking industry' loan book grew by 16\%. Risk management is now emerging as a key priority area for the industry after the interest capping rate law came into force in August 2016. Banks are taking conservative approach to conducting their business because asset allocation is shifting in favor of less risky assets like cash and government securities. As at September 2016, the government securities contributed 24\% of the industry' balance sheet compared to an $18 \%$ average between 2011 and 2015. The impact of the interest cap has led to loan books grow at a much slower pace than in the past. Banks have experienced declined growth in earnings per share in the first quarter of 2017, with a slight compression in net margins, and this has adversely affected the profitability of banks.

The Banking Amendment Act, 2016 came into force in August 2016 capping the maximum interest rate chargeable by banks at $4 \%$ above the prevailing base rate set by CBK. The capping is causing a great risk because most banks are shying away from issuing personal loans and lending to small and medium sized enterprises making credit inaccessible to borrowers because the banks prefer investing in government securities. There is increased liquidity in the economy where some banks are no longer accepting fixed deposits as a form of investment. This may lead to contraction of the economy as businesses and individuals find it hard to access credit and this will affect the country' productivity in the long run. Banks are merging their operations to the extent to staff being retrenched due to redundancy and to cut costs.

In 2016, the banking industry as a whole remained liquid and the short-term liquidity challenges faced by small and some medium banks was a sign of skewed distribution of liquidity. Most depositors migrated their deposits to selected medium-sized banks and large-sized banks while most large banks rationed lines of credit affecting mainly banks in small peer group and some in the medium peer group. Despite the migration, CBK provided liquidity support to the banking sector to mitigate these challenges. In addition, the recent development in the banking sector in terms of interest rate caps is expected to constrain the access to finance for SME's in the coming years and already in 2016, the interest rates declined tremendously. As a result of non-compliance CBK placed two banks under receivership in 2015 (i.e. Dubai Bank Ltd and Imperial Bank Ltd) and one more in 2016 (i.e. Chase Bank Ltd). In 2017, the CBK lifted the moratorium on licensing new banks and seen has led to two foreign entities being licensed i.e. Dubai Islamic Bank Ltd and Mayfair Bank Ltd.

During the global financial crisis of 2008/2009, the delayed recognition of credit losses on loans was identified as weakness in the existing accounting standard for banks. This prompted the International Accounting Standards Board (IASB) to issue International Financial Reporting Standard (IFRS) 9 Financial Instrument that replaces International Accounting Standards (IAS) 39 and it will come into effect from January 2018. The new standard requires entities to account for expected credit losses from when financial instruments are first recognized and to recognize full lifetime expected losses on a timelier basis. The standard is viewed as a positive move that will see banks increase their level of provisioning and this will increase shareholders' confidence in the operations of the banks.

Lastly, objective three and four determined the moderating effect of macroeconomic variable on the relationship between bank size, financial risk exposure and financial performance of Commercial Banks in Kenya. The macroeconomic variable was measured by Kenya GDP growth rate. The results of the Kenya GDP growth rate in 
models 1, 2, and 3 shows a minimal effect on the relationship between bank size and financial risk exposure on the financial performance of commercial banks in Kenya. This is inconsistent with the findings of Rao \& Lakew (2012), Ramadan et al., (2011) and Ongore \& Kusa (2013). The relationship between bank size and financial risk exposure on financial performance is mixed because it is negatively related to ROA. This relationship supports that Kenya GDP growth rate is neutral towards financial performance (Flamini et al., 2009).

The Kenyan economy continues to register macroeconomic stability with low and stable interest rates and competitive exchange rate to support exports. The short-term interests have remained fairly stable and low oscillating around the Central Bank Rate (10\%), reflecting sufficient liquidity in the market. Kenya's external position has so far strengthened supported by a narrower current account deficit. The current account deficit narrowed to $6.18 \%$ of GDP in March 2017, supported by improved export earnings and diaspora remittances. The government' prudent economic policies have helped the National Treasury anchor the conditions for strong and stable growth. According to the Economic Intelligence Unit (EIU), investment in infrastructure, strong household consumption, closer integration with East Africa Community and recovery in tourism numbers led to the increase in the country' GDP from 5.6\% in 2015 to $5.8 \%$ in 2016.

The EIU expects the country' GDP growth to decline to 5.5\% in 2017 largely due to a slowdown in investments as the country heads towards the general elections. Reduced lending to the private sector, the result of the enactment of the Banking (Amendment) Act that caps lending rates, will also contribute to a decline in GDP. On the other hand, IMF's report indicates that Kenya's economy has continued to perform well. The real GDP growth increased in 2016, inflation remain within the target range, and the current account deficit has narrowed. The overall macroeconomic outlook is overall positive, including robust growth and reduced external imbalances. However, interest rate controls are likely to reduce access to credit, weighing on growth. They also complicate monetary policy and adversely affect banking sector profitability, especially for small banks. Although the adverse effects of the controls are manageable in the near term, if maintained, they could potentially pose a risk to financial stability. Therefore, it is essential to remove these controls, while taking steps to prevent predatory lending and increase competition and transparency of the banking sector.

\subsection{Recommendations for Policy}

From the study findings and conclusions, the study makes several recommendations:

Objective one sought to determine the effect of bank size on financial performance of Commercial Banks in Kenya: Policy directions should be made by Treasury or Central Bank of Kenya such as increasing capital size, liquidity requirements, and deposit insurance premiums may aid in enlarging the size of all banks to a level where they are fairly equal with none having relative market power to drive process in the market, thereby ensuring an ideal environment for competitive pricing and operational efficiency. So far only twenty-one banks have complied with the capital requirement as stipulated in the Banking Act. Central Bank of Kenya, Bank Supervision should ensure the remaining banks comply to minimize cases of non-compliance that may result banks to be placed under receivership or statutory management. CBK should also encourage mergers and acquisitions so as to have few banks offering quality services and the shareholders earning a better return on their investments. This can be achieved by CBK emphasizing commercial banks to comply with the Basel III requirements and the Prudential Guidelines.

Objective two was to establish the effect of financial risk exposure on financial performance of Commercial Banks in Kenya: The Central Bank of Kenya in conjunction with Treasury should review the risk policies with emphasis on the liquidity risk so as to guide the mitigation of risk in the banking industry. Generally, this will aid in fostering the liquidity, solvency and proper functioning of a stable banking industry in Kenya. This will also minimize cases of banks being put under receivership or statutory management due to noncompliance e.g. the case Dubai Bank Ltd. The interest cap is posing a great risk to Kenya' financial stability and this will slow the country's target of being the regional leader in financial inclusion. The National Treasury, KBA and CBK are currently undertaking a comprehensive assessment of the impact of the interest rate capping law on credit expansion to the private sector which has slowed down and on the economic growth. Banks should be innovative and source for other avenues of revenue creation because the government is unlikely to repeal the rate cap.

Objective three and four determined the moderating effect of macroeconomic variable on the relationship between bank size, financial risk exposure and financial performance of Commercial Banks in Kenya: The stability of banking industry in Kenya is supported by the stability of the macroeconomic environment. The Treasury and CBK should revise macroeconomic policies that will stabilize the economy to ensure a resilient environment for banking industry to operate in e.g. coming up with prudent economic policies that will help reduce public debt, strengthen banking industry supervision to ensure the banking industry is well capitalized, among others. The government should consider reviewing the interest controls so as to encourage capital flows and new security incidents. Other avenues to be 
reviewed by the National Treasury is the inflation rate especially the domestic fuel prices and the balance

\section{Conclusion}

Under financial performance, average ROA in Kenya is consistent with average ROA in Sub-Saharan Africa (SSA) implying that Commercial Banks' ROA in Kenya is about average of SSA. The bank size (i.e. assets, loan accounts, and deposits) is positive implying that bank size plays a major role in impacting on the financial performance of commercial banks in Kenya; this finding supports the Structure Conduct Performance and the Relative Market Power hypothesis. Under bank size (loan accounts), the results indicate a high loan book that may lead to increased non-performing loans thereby negatively impacting on the financial performance of commercial banks in Kenya.

Objective one sought to determine the effect of bank size on financial performance of Commercial Banks in Kenya by analyzing the structural performance relationship existing in the banking industry using the Structure-Conduct-Performance literature. Bank size was measured by the bank size based on net assets, loan accounts and deposits. The results indicate that bank size is positive; this implies that bank size plays a major role in impacting on the financial performance of commercial banks in Kenya. The results also imply that the main source of financial performance in the Kenyan banking industry is as a result of structure or collusive power and not efficiency.

Objective two was to establish the effect of financial risk exposure on financial performance of Commercial Banks in Kenya. The financial risk exposure was measured by the market risk, credit risk and liquidity risk. There are mixed regression results in Model 1, Model 2 and Model 3. In Model 1, 2 and 3, the regression analysis results indicate that market risk has minimal effect on financial performance of commercial banks in Kenya. This means that the overall market movement in the financial market has minimal impact on the financial performance in the banking industry. This is somehow true because during the global financial crisis in 2007/2009, there was minimal impact on the financial performance of commercial banks in Kenya because banks had positive results/growth. This further implies that financial risk exposure can have minimal or major effect on the financial performance of banks in Kenya depending on the risk policies that are in place.

Objectives three and four determined the moderating effect of macroeconomic variable on the relationship between bank size, financial risk exposure and financial performance of Commercial Banks in Kenya. The macroeconomic variable was measured by Kenya GDP growth rate. The results of the Kenya GDP growth rate in models 1, 2, and 3 shows a minimal effect on the relationship between bank size and financial risk exposure on the financial performance of commercial banks in Kenya. The relationship between bank size and financial risk exposure on financial performance is mixed because it is negatively related to ROA.

\subsection{Contribution of the Study to the Existing Body of Knowledge}

This study makes several contributions to the existing body of knowledge. The study finds that bank size and financial risk exposure have significant impact on the financial performance of commercial banks in Kenya. Also, the review of the theoretical and empirical literature made in the study and contributes to past reviews made by past scholars on the financial performance of commercial banks in Kenya. The descriptive statistics can be integrated with other econometric models to determine the effect of bank size and financial risk exposure on financial performance of commercial banks in Kenya. Finally, the scope, limitations and findings of this study presents room for conduct of more empirical researches within the S-C-P framework.

\section{References}

Aburime, U. (2005). Determinants of Bank Profitability: Company-Level Evidence from Nigeria. Nigeria: University of Nigeria, Enugu Campus.

Acharya, V. V., Hasan, I., \& Saunders, A. (2002). Should Banks Be diversified? Evidence from Individual Bank Loan Portfolios. BIS working paper No. 118. https://doi.org/10.2139/ssrn.293295

Adongo, J., Stork, C., \& Hasheela, E. (2005). Measuring the alternative profit X efficiency of Namibia's banking industry. Research Report 36. Namibia: NEPRU.

Aikaeli J. (2008). Commercial Banks Efficiency in Tanzania, Bank of Tanzania Monetary and Financial Affairs Department. A Paper Presented in a CSAE Conference on "Economic Development in Africa".

Al-Tamimi, H., \& Hassan, A. (2010). Factors Influencing Performance of the UAE Islamic and Conventional National Banks. Department of Accounting, Finance and Economics, College of Business Administration, University of Sharjah.

Arif, M., Khan, M. Z., \& Iqbal, M. (2013). Impact of Bank Size on Profitability: Evidence From Pakistan. International Journal of Applied Research, 2.

Berger, A. N., \& Humphrey, D. B. (1997). Efficiency of financial institutions: International survey and directions for 
future research. European Journal of Operational Research, 98(2), 175-212. https://doi.org/10.1016/S0377-2217(96)00342-6

Bikker, J. A., \& Bos, J. W. B. (2005). Trends in competition and profitability in the banking industry: a basic framework. Suerf Series, 2005/2.

Bordens, K. S., \& Abboth, B. B. (2002). Research Design and Methods: A Process Approach. New York: McGraw Hill Publisher.

Central Bank of Kenya. (2013). Bank Supervision Annual Report. Kenya.

Central Bank of Kenya. (2016). Bank Supervision Annual Report. Kenya.

Creswell, J. W. (2007). Educational research (3rd ed.). Thousand Oaks, CA: Sage.

Demirguc-Kunt, A., \& Huzinga, H. (2000). Financial Structure and Bank Profitability. World Bank Research Paper, Washington D.C.

Feinstein, A. R. (2002). Misguided efforts and future challenges for research on diagnostic tests. J Epidemiol Community Health, 56, 330-2. https://doi.org/10.1136/jech.56.5.330

Fiordelisi, F., Marques-Ibanez, D., \& Molyneux. P. (2010). Efficiency and risk in European banking. Journal of Banking and Finance, 35, 1315-1326. https://doi.org/10.1016/j.jbankfin.2010.10.005

Flamini, C., Valentina C., McDonald, G., \& Liliana, S. (2009). The Determinants of Commercial Bank Profitability in Sub-Saharan Africa. IMF Working Paper. https://doi.org/10.5089/9781451871623.001

Frees W. E., (2004). Longitudinal and Panel data: Analysis and Applications in the Social Sciences. Press syndicate of the University of Cambridge, United Kingdom. https://doi.org/10.1017/CBO9780511790928

Ikhide, S. I. (2008). Measuring the operational efficiency of commercial banks in Namibia, South African Journal of Economics, 76(4), 586-95. https://doi.org/10.1111/j.1813-6982.2008.00214.x

Isik, I., \& Hassan, M. K. (2002). Cost and Profit Efficiency of the Turkish Banking Industry: An Empirical Investigation. The Financial Review, 37(2), 257-280. https://doi.org/10.1111/1540-6288.00014

Kamau, A., \& Were, M. (2013). What Drives Banking Industry Performance in Kenya?. Global Business and Economics Research Journal, 2(4), 45-59.

Kamau, W. A. (2011). Intermediation Efficiency and Productivity of the Banking industry in Kenya. Interdisciplinary Journal of Research in Business, 9, 12-16.

Kiweu, J. M., \& Ndulu, K. J. (2012). Factors affecting institutional transformation for regulated MFIs.

Kraft, E., Hofler, R., \& Payne, J. (2002): Privatization, Foreign Bank Entry and Bank Efficiency in Croatia: A Fourier-Flexible Function Stochastic Cost Frontier Analysis. Working Paper, Croatian National Bank.

Marrison, C. (2005). The fundamentals of risk measurement. New York: McGraw-Hill.

McManus, L. (2011). Accounting for Customers: The impact of Contextual Factors and Implications for Management Decision-Making. Working paper, Griffith University, Gold Coast, Qld.

Mohan, R. (2003). Transforming Indian Banking: In Search of a Better Tomorrow. IBA Bulletin, 25(3).

Ncube, M. (2009). Efficiency of the Banking industry in South Africa. A Paper presented at African Interdisciplinary Journal of Research in Business, 1(9), 12-26.

Ongore, V. O., \& Kusa, G. B. (2013). Determinants of financial performance of commercial banks in Kenya. International Journal of Economics and Financial Issues, 3(3), 237-252.

Saunders, M., Lewis, P., \& Thornhill, A. (2009). Research Methods for Business Students (5th ed.). Harlow: Financial Times Prentice Hall.

Sharma, B. R. (2003). Bank Frauds-Prevention \& Detection. Universal law Publishing Co. Pvt. Ltd.

Tregenna, F. (2009). The Relationship Between Unemployment and Earnings Inequality in South Africa. Cambridge Working Papers in Economics 0907, Faculty of Economics, University of Cambridge. 